AGRARIS: Journal of Agribusiness and Rural Development Research

Vol. 7 No. 1 January - June 2021, Pages: 64-77

Article history:

Submitted: August 26 6 th 2019

Accepted: August $14^{\text {th }}, 2020$
Ray March Syahadat ${ }^{1}$, Priambudi Trie Putra ${ }^{1}$, Ismail Saleh ${ }^{2}$, Tandri Patih $^{3}$, Anendawaty Roito Sagala ${ }^{1}$, Dimas Muhammad Thoifur ${ }^{1}$

${ }^{1}$ Landscape Architecture Department, Faculty of Civil Engineering and Planning, National Institute of Science and Technology

${ }^{2}$ Agrotechnology Department, Faculty of Agriculture, Swadaya Gunung Jati University

${ }^{3}$ Mathematics Tadris Department, Faculty of Tarbiyah and Teacher Training, Kendari State Islamic Institute (IAIN Kendari)

*) Correspondence email: ray.arl@istn.ac.id

\title{
Visual Quality Protection of Ciboer Rice Fields to Maintain the Attraction of Bantar Agung Tourism Village
}

DOI: https://doi.org/10.18196/agraris.v7i1.6960

\begin{abstract}
Bantar Agung Village in Majalengka Regency, West Java Province, is developing agriculturally-based tourism. The Ciboer Rice Fields area is one of the attractions in the village of Bantar Agung that presents the visual beauty of the rice field landscape. New agro tourism opportunities will be developed in this area. The study has aimed to evaluate the visual quality of the Ciboer Rice Fields and how it would be affected by agro tourism-related changes. Data were analyzed using Kendall's W test, scenic beauty estimation (SBE), semantic differential (SD), factor analysis, and multidimensional scaling (MDS). It is found that when more objects are added to the Ciboer Rice Fields landscape, the value of beauty is diminished. Village regulations are needed to protect the visual experience of the Ciboer Rice Fields.
\end{abstract}

Keywords: agriculture, agro tourism, beauty, landscape, tourism.

\section{INTRODUCTION}

The terraced rice fields in Bantar Agung Village (usually written as Bantaragung), Majalengka Regency, are known as the Ciboer Rice Fields. This area, one of several agricultural tourism attractions in Bantar Agung Village, was developed by local people with several purposes. First, as a source of community income; second, to prevent the conversion of agricultural land; third, to maintain tradition; and finally, to support the Cipeuteuy Waterfall tourism.

The rice fields in Bantar Agung Village are currently being developed into organic farming areas favored by the local community (Saleh, Eviyati, Mardhatilla, \& Wahana, 2018; Wahana, 2018). Previous research conducted by Yuniarsih, Marsono, Pudyatmoko, \& Sadono (2014) indicated that there are other agricultural potentials besides rice, such as durian, banana, melinjo, picung, jackfruit, and jengkol. In short, the culture of agriculture in Bantar Agung Village cannot be separated from the traditions of the community. Palmer (2011) states that the existence of agricultural land, especially rice fields, has not only economic but also social impact. The existence of agricultural land with economic and social impacts is prone to erosion along with changes in the structure of livelihoods. Rohmadiani (2011) states that there is a relationship between changes in the structure of livelihoods from the primary sector to 
the secondary sector due to land conversion. Land conversion also causes population migration out of an area as individuals attempt to find work. For this reason, the agriculturallyfocused development of the Ciboer Rice Fields is one of several efforts to maintain the sustainability of livelihoods for the people of Bantar Agung Village.

Curug Cipeuteuy is a part of the Mount Ciremai National Park (TNGC) area that is managed independently by the community, based on the provisions of the national park (Anindisa, Basuni, \& Sunarmito, 2017; Yuniarsih et al., 2014). This area has the potential to become a major destination in West Java (Muslih, Sunarminto, \& Avenzora, 2011; Saputra, Susdiyanti, \& Supriono, 2012). For Bantar Agung Village, Curug Cipeuteuy is the pride of the residents because it has received the Indonesian Charm Award (API) from the Ministry of Tourism as a hidden paradise (Thoifur et al., 2018). People wish to maintain the sustainability of Curug Cipeuteuy because of the sense of community closeness. One way to approach this goal is for the community to develop the Ciboer Rice Fields as an alternative tour, keeping tourists from focusing solely on Curug Cipeuteuy. A concentration of tourists at one point will cause ecological disturbances due to exceeding the area's carrying capacity (Putra et al., 2018).

The level of awareness of the Bantar Agung Village community towards the protection of local resources is quite good. The community and village government have concerns about the sustainability of Ciboer Rice Fields if tourism development is extremely successful. Currently, a Ciboer Pass has been built in the Ciboer Rice Fields area, providing a tourist attraction that supports watching the landscape in the direction of the rice fields.

The village authorities plan to develop the Ciboer Rice Fields area not only by providing passive attractions, but also by offering active attractions that involve organic agricultural agrotourism activities. Such activities will be implemented thoroughly in Bantar Agung Village. Research on agrotourism in Bantar Agung Village has never been conducted regarding the Ciboer Rice Fields area; it is more focused on the Cipeuteuy and TNGC areas (Anindisa et al., 2017; Thoifur et al., 2018; Yuniarsih et al., 2014; (Yuningsih \& Herdiansyah, 2019). Therefore, it is necessary to study the protection of visual quality so that new objects that have been planned to support tourism activities can be placed appropriately. Many studies on visual quality evaluation have been carried out, consisting of evaluations of existing arrangements, before and after changes, and development plans (Adriani, Hadi, \& Nurisjah, 2016; Budiyono \& Soelistyari, 2016; Franco, Franco, Mannino, \& Zanetto, 2003; Putra et al., 2018; Wardiningsih, Syahadat, Putra, Purwati, \& Hasibuan, 2017). Previously reported evaluations described benefits for the protection of visual resources that have significant economic, ecological, and socio-cultural impacts.

Based on the description above, this article aims to evaluate the visual quality of the Ciboer Rice Fields in several development scenarios based on plans made by the Bantar Agung Village authority. The results are useful as recommendations for making village regulations for the visual protection of the Ciboer Rice Fields. Preserving visual resources means helping to maintain the economic sustainability of the community (Ekayani, Nuva, Yasmin, Sinaga, \& Maaruf, 2014; Satria, 2009; Utama, 2016). 


\section{RESEARCH METHOD}

This research was conducted in April 2018 in Bantar Agung Village, Sindangwangi District, Majalengka Regency, West Java Province. The research implementation was divided into several stages: focus group discussion (FGD), document collection, image taking, image processing, questionnaire distribution, data processing, and interpretation of data processing results.

The FGD activities involved village and sub-district authorities, village youth, villagers, cooperatives, managers, academics, and landscape planners. Documents collected are in the form of village plans for developing agro tourism in the Ciboer Rice Fields. The photography was accomplished by taking pictures with a perpendicular angle to the diameter at breast height (DBH) from the Ciboer Pass point. The images were then processed using Adobe Photoshop software based on the development plans obtained from the document collection stage (Figure 1).
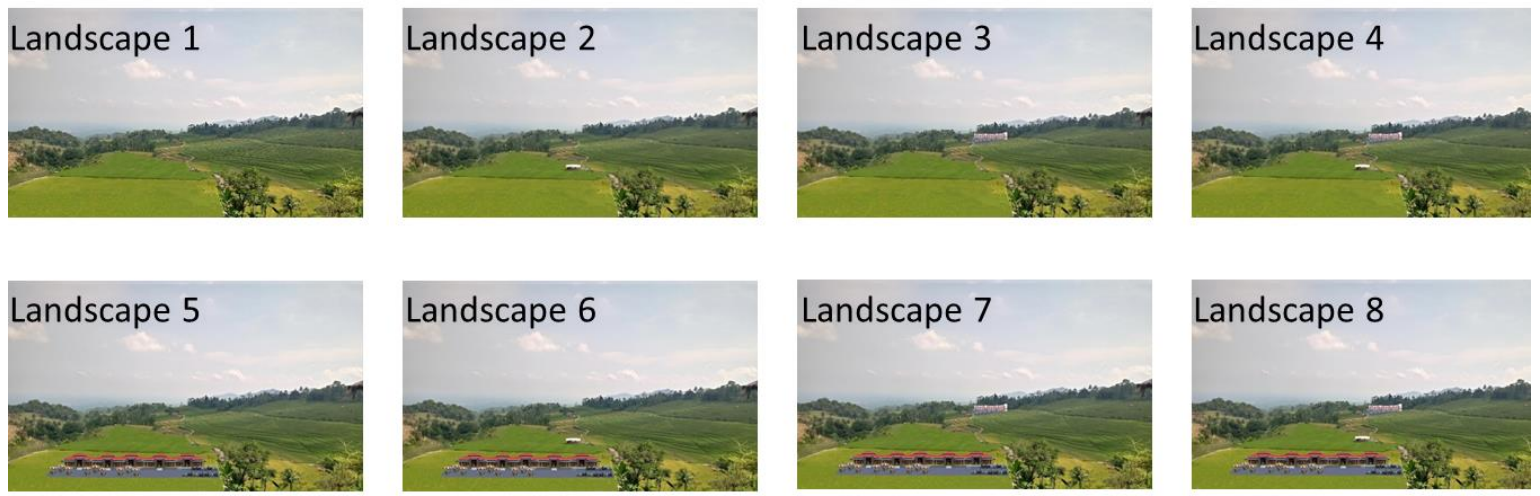

FIGURE 1. LANDSCAPE CHANGE SCENARIOS THAT WERE ASSESSED FOR VISUAL QUALITY

Based on the results of preliminary observations and information from the manager, the average number of daily visitors to the Ciboer Rice Fields is 10 people. Based on this data, the questionnaire was distributed online to 118 respondents as a randomly selected sample. This number, selected to meet a confidence interval of 0.1 and a confidence level of $99 \%$ using the assumption of an average daily visitor population, was tested using The Survey System software. The background of the selected respondents is that they were domiciled outside Bantar Agung Village. This approach was intended to represent tourists as visitors so that they would be more objective in assessing the beauty of the Ciboer Rice Fields as the main attraction of the tourist area. The questionnaire was distributed using the Google Forms application. Respondents provided ratings on a scale of 1 to 10 to assess visual quality. Respondents also rated the impression they received when viewing each image on a scale of 3 to 3. The impression was formulated into five bipolar scales: ugly-good, messy-tidy, aridlush, dirty-clean, and lame-balanced. The data were then analyzed using Kendall's W, Scenic Beauty Estimation (SBE), Semantic Differential (SD), factor analysis, and Multidimensional Scaling (MDS), the last of which refers to the method that was used by Syahadat et al. (2019). The reason for using this approach is that it is a refinement of approaches that have been carried out by similar previous studies (Budiyono, 2015; Hamdani, 2017; Rejoni, 2017; Rada 
et al., 2019; Murna, Asmiwyati, \& Sukewijaya, 2020). Thus, the approach chosen and carried out in this study can make it easier to draw conclusions so that decisions that are based on them are accurate and unbiased.

Kendall's W is used to see whether there are differences that may result from a given scenario. This test was chosen because the data used were ordinal and paired data (Suliyanto, 2014). Previously, in similar studies in assessing visual quality, researchers usually tested it directly using the SBE analysis. Even if it is not significant for visual quality, the results of the Kendall's W test can be used immediately to draw conclusions. The formula used can be seen in Equation 1.

$$
\mathrm{W}=\frac{12 \sum R i^{2}-3 n^{2} k(k+1)^{2}}{n^{2} k\left(k^{2}-1\right)}
$$

Information:

$$
\begin{array}{ll}
\mathrm{W} & =\text { Kendall's W value } \\
\mathrm{n} & =\text { sample size (number of lines/observations) } \\
\mathrm{k} & =\text { number of samples (number of columns) } \\
\mathrm{Ri} & =\text { the number of rankings in the column }
\end{array}
$$

Beauty is a non-parametric and qualitative type of data, meaning that the standard point is not easily known. The SBE method, which was later introduced by Daniel \& Boster (1976) to address this problem, is used to estimate the visual quality of a landscape based on respondents' perceptions. As used by Daniel \& Boster (1976), the standard sets a critical value used for drawing conclusions, namely that an SBE value above 20 indicates a strongly positive aesthetic meaning. SBE values between 20 and -20 are neutral. SBE values below - 20 imply an especially unaesthetic meaning; in this case, the visual quality is very poor. The formula used can be seen in Equation 2.

$$
S B E_{x}=\left(Z_{y x}-Z_{y o}\right) \times 100
$$

Information:

$\mathrm{SBE}_{\mathrm{x}}=$ Estimated value of landscape beauty in the $x$-scenario

$Z_{\mathrm{yx}} \quad=$ Average $z$ value of the $x$-scenario landscape

$Z_{\mathrm{yo}} \quad=$ The average $z$ value of a landscape under a certain scenario as a standard

$\mathrm{SD}$ analysis is used to provide an assessment of respondents' reactions to the resulting impression (Equation 3). The SD data were then used for MDS analysis and factor analysis. MDS analysis is used to see what impressions are attached to a particular landscape. Factor analysis is used to explain the variables that are interrelated in landscape groups.

$$
\bar{x}_{i j}=\frac{\sum_{i=1}^{n} x_{i j}}{n}
$$

Information:

$\bar{X}_{i j} \quad=$ the mean weighted score by respondents given the landscape scenario for criterion $j$

$X_{i j} \quad=$ weighted value assigned by each respondent for the $i^{\text {th }}$ landscape scenario criterion $j$

$\mathrm{n} \quad=$ number of respondents

$\mathrm{i} \quad=$ landscape scenario $(1,2,3, \ldots, \mathrm{n})$

$\mathrm{j}=$ criteria $(1,2,3, \ldots, \mathrm{n})$ 


\section{RESULT AND DISCUSSIONS}

\section{Agro Tourism Development Plan}

The results of the FGD and document searches show that Bantar Agung Village has a desire to develop the rice fields by adding several facilities to support agrotourism. The three areas in which facilities will be developed are in the background, middleground, and foreground towards the Ciboer Pass point of view (Figure 2). The three terms are used by landscape architecture science in dividing what is visible from a given point of view.

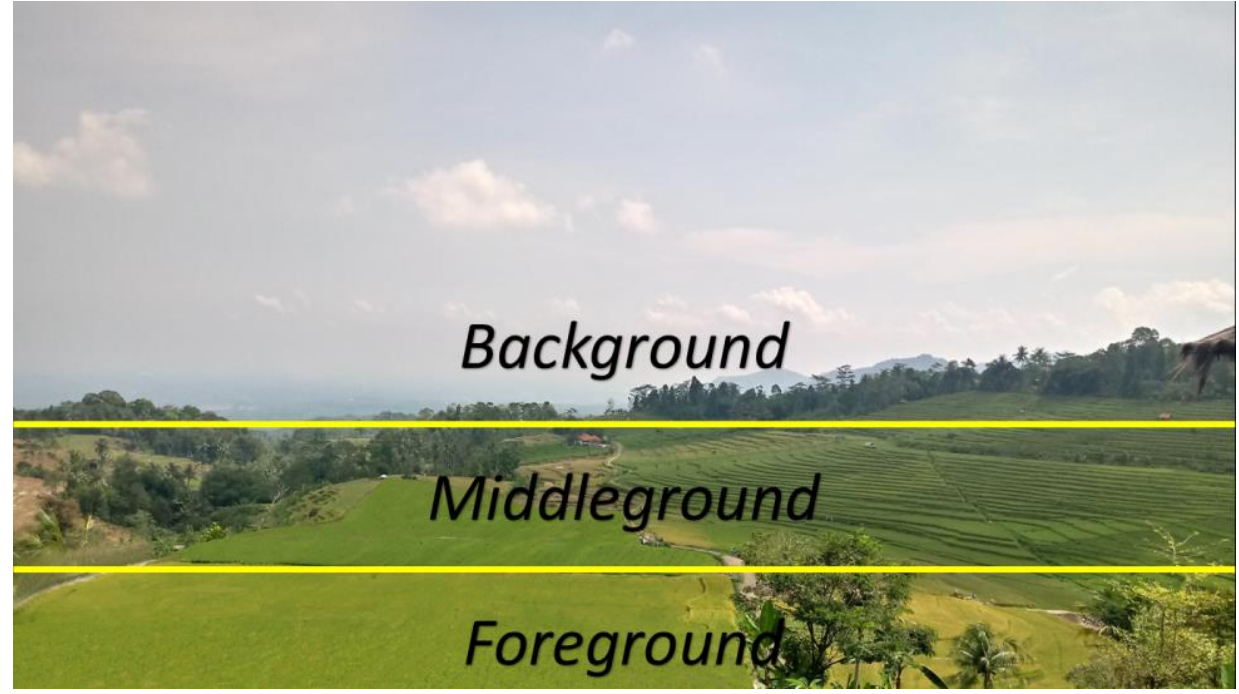

FIGURE 2. VISUALIZATION OF THE DISTRIBUTION OF CIBOER RICE FIELDS FROM CIBOER PASS POINT

The desired facilities mentioned in the FGD results include shops, gazebos, and shelters. Shops are planned for the background area, a gazebo for the middle ground area, and a shelter for the foreground area. So far, only the middle ground gazebo has been built. For the current analysis, this information is depicted to support the visual analysis of the Ciboer Rice Fields landscape. This rice field landscape has multiple owners, so it is prone to conflicts of interest. However, the view towards the rice fields is a visual resource that serves as a borrowed landscape from the Ciboer Pass points. Budiyono (2015), in his research, reports that the addition of objects to a landscape can affect its aesthetic value. Thus, careful analysis and planning are needed to minimize the risk of visual damage.

The village authority wants to use a scientific study as a basis for making village regulations to prevent unwanted events in the future related to the development of this rice field area. It can be said that there is no awareness of visual quality conservation in Indonesia. In fact, there are no regulations governing the development of an area. An example of a country that has concerns about this problem is Japan. The country was intensely reported upon by scientific studies in the 1980s-1990s (Arifin \& Masuda, 1996; Arifin \& Masuda, 1997; Kumagai \& Yanase, 1984).

The tourist attractions offered in the Ciboer Rice Fields emphasize organic rice cultivation activities, which include pre-planting, planting, harvesting, and post-harvest activities. This situation aligns with the results of research stating that organic agriculture has the potential to be developed into agro tourism (Preeyanan, Pakkapong, \& Duanrung, 2015). 
In addition, attractions are also planned for plowing the fields with buffaloes, buffalo bathing activities, composting practices, culinary tours involving organic ingredients, and sales of fresh and processed organic agricultural products, as well as outbound activities and river tubing. To support these activities, the village plans to add facilities around the Ciboer Rice Fields area. These additions need to be analyzed so that misplacement does not result in a decrease in the visual quality of the landscape. Moreover, Ciboer Pass is a tourist attraction that first existed in Bantar Agung Village, which already has its own market. The market itself is a landscape viewing attraction and is one of the village icons along with Cipeuteuy Waterfall.

\section{Visual Quality Analysis}

The results of the analysis using the Kendall's W test show that there is a significant difference in the visual quality of each additional element in the Ciboer Rice Fields landscape, as indicated by the chi-square value of 175.89 . The calculated chi-square value is greater than the chi-square table. The average rankings from highest to lowest are Landscapes 2, 1, 3, 4, 5, 6,7 , and 8 , respectively (Table 1 ). In principle, the average ranking value is only able to explain that there are differences in ranking between paired sample scenarios because the data used is on an ordinal scale. This information was not sufficient to determine which scenarios pose a risk to visual damage, so further testing was carried out using SBE analysis.

The results of the SBE analysis show that when objects are added to the foreground, the aesthetic value will decrease. For this reason, adding objects to the foreground for the development of the Ciboer Rice Fields landscape should be avoided. Adding more objects will also decrease the aesthetic value of a landscape. This is evidenced by the low SBE value in Landscape 8, namely the landscape with objects in the foreground, middle ground, and background of the Ciboer Rice Fields (Figure 3). This outcome is in line with research conducted by Adriani et al., (2016), which states that the less human intervention in a landscape, the better the visual quality of the landscape.

\begin{tabular}{lc} 
TABLE 1. KENDAL'S W TEST RESULTS OF CIBOER RICE FIELDS SCENARIO \\
\hline Variable & Average Ranking \\
\hline Landscape 1 & 5.51 \\
Landscape 2 & 5.80 \\
Landscape 3 & 5.18 \\
Landscape 4 & 5.11 \\
Landscape 5 & 3.89 \\
Landscape 6 & 3.81 \\
Landscape 7 & 3.46 \\
Landscape 8 & 3.24 \\
\hline N & 118 \\
Kendall's W & 0.21 \\
Chi-Square & 175.89 \\
Df & 7 \\
Asymp. sig & $0.00^{*}$ \\
\hline Note: $\left(^{*}\right)$ indicates significance at the level $\alpha<1 \%$
\end{tabular}

Factor analysis explains the correlation of the independent indicators on the assessment. The results of the factor analysis show that the landscape options cluster into two 
groups of differing character (Table 2). The correlation results show that the first group consists of Landscapes 3, 4, 5, 6, 7, and 8, and the second group includes Landscapes 1 and 2 only. Referring to the SBE values in Figure 3, Landscape 1 and 2 are the landscapes with the most visual quality. Height and the least addition of objects with correlation values of 0.798 and 0.681 , respectively. These results illustrate that to avoid visual damage to the Ciboer Rice Fields view, the scenarios in Landscape 1 and Landscape 2 can be used as alternatives.

\section{TABLE 2. FACTOR ANALYSIS RESULTS OF CIBOER RICE FIELDS SCENARIO}

\begin{tabular}{lcc}
\hline Variable & \multicolumn{2}{c}{ Component $^{*}$} \\
\cline { 2 - 3 } & 1 & 2 \\
\hline Landscape 1 & 0.421 & 0.798 \\
Landscape 2 & 0.577 & 0.681 \\
Landscape 3 & 0.755 & 0.323 \\
Landscape 4 & 0.857 & 0.150 \\
Landscape 5 & 0.916 & -0.221 \\
Landscape 6 & 0.913 & -0.304 \\
Landscape 7 & 0.919 & -0.317 \\
Landscape 8 & 0.896 & -0.368 \\
\hline Note: ${ }^{*}$ correlation value & &
\end{tabular}

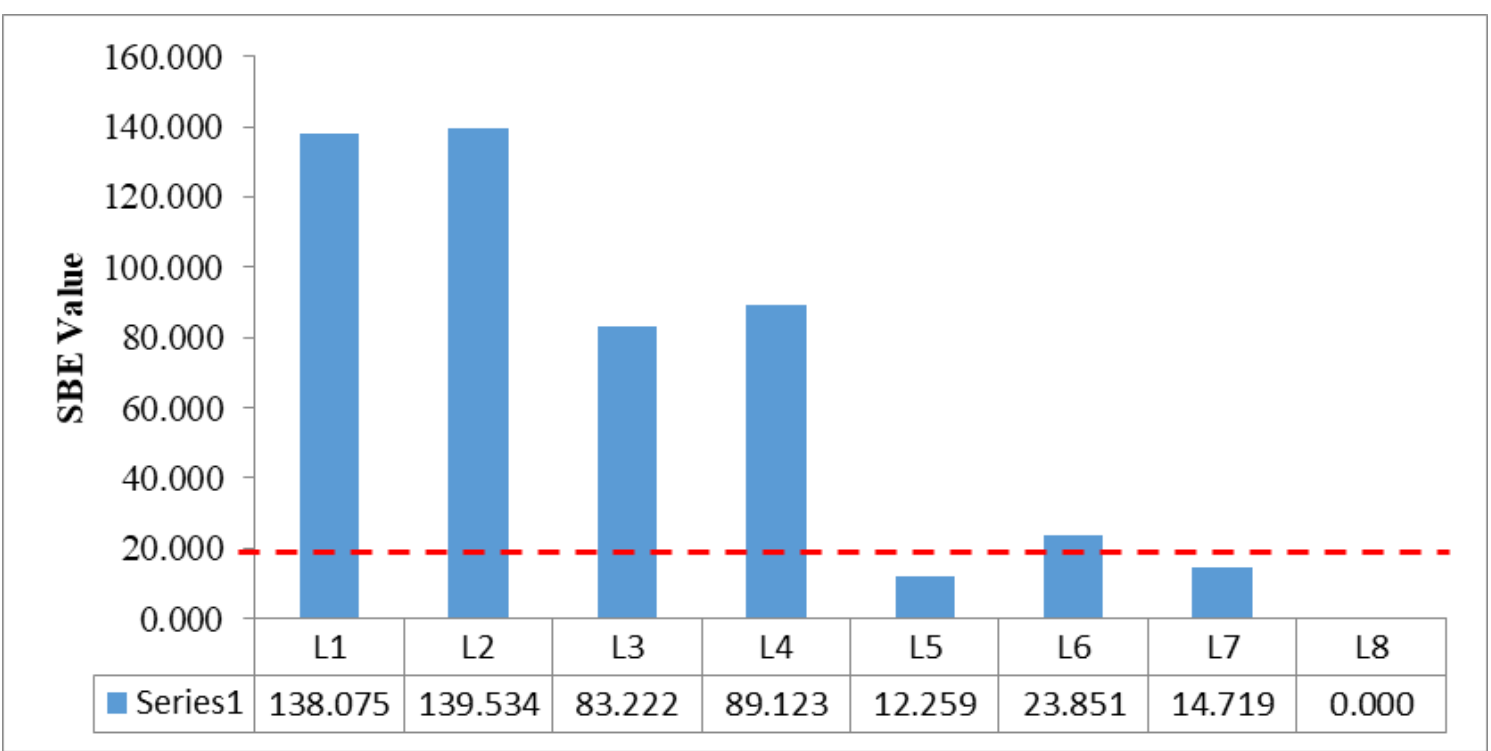

FIGURE 3. SBE VALUE GRAPH OF CIBOER RICE FIELDS SCENARIO

The MDS analysis will further clarify which descriptors represent the limiting factors for why Landscapes 1 and 2 are preferred. Based on the results of the MDS analysis in Figure 4, Landscapes 1 and 2 are closer to row 4 which represents the scale clean-dirty. The SD analysis results in Figure 5 show that Landscapes 1 and 2 are considered cleaner than the others by the respondents. Landscapes 5, 6, 7, and 8 are the four landscapes whose visual quality is considered to be the poorest, primarily due to row 5 (dirty-clean) and row 2 (messytidy). Furthermore, other landscapes with low SBE values are more influenced by row 5 on the SD chart, which is considered unequal by respondents.

The four landscapes noted above are considered dirty and messy. A messy impression has also been reported in previous studies as a limiting factor in whether or not a visual 
landscape is liked (Syahadat et al., 2019). Research conducted by Rejoni (2017) also shows similar indications. However, because the MDS analysis was not carried out, it is not known whether these factors are the actual limiting factors that cause a visual landscape to be liked or not.

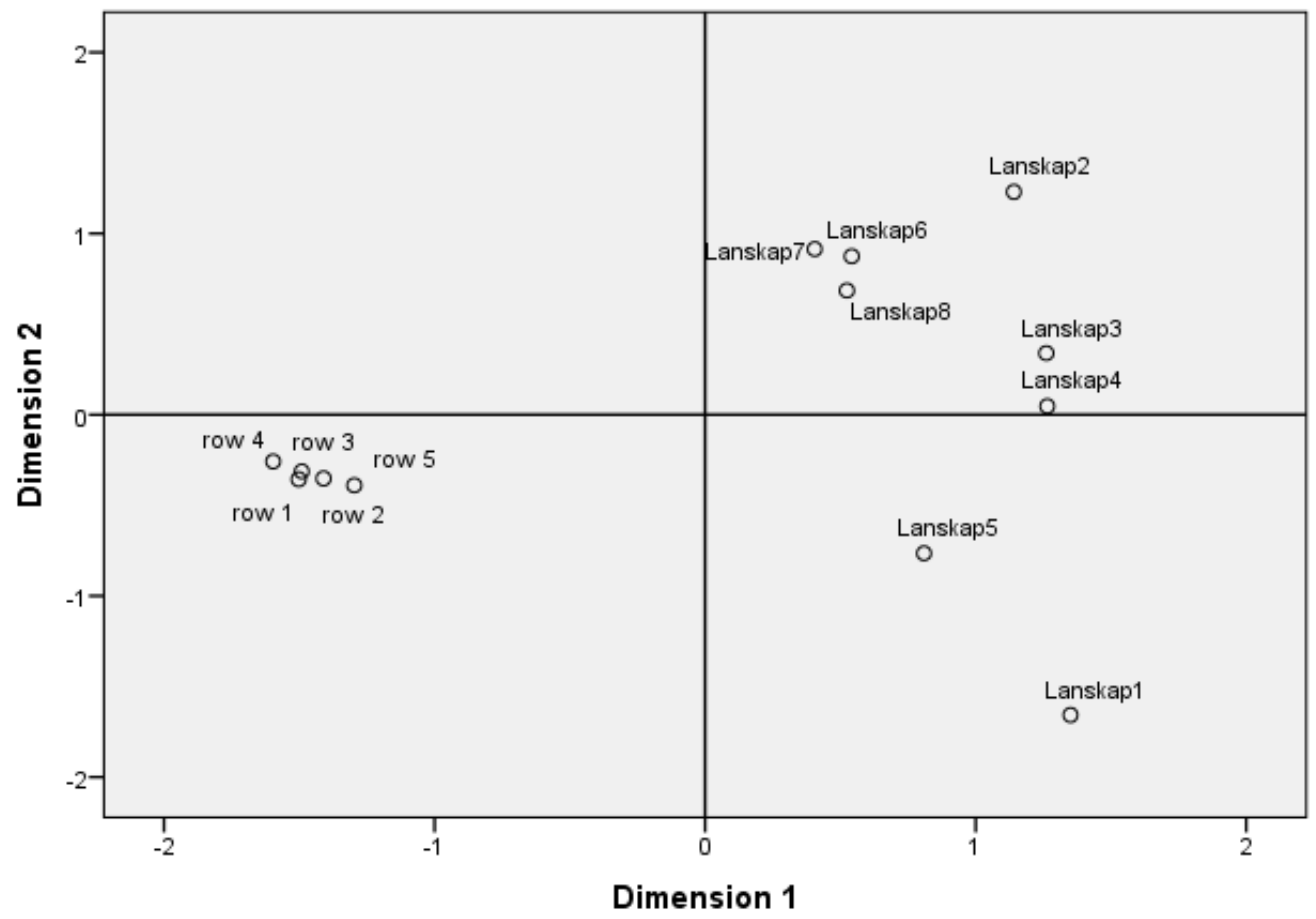

FIGURE 4. MDS DERIVED STIMULUS CONFIGURATON EUCLIDEAN DISTANCE MODEL CHART OF CIBOER RICE FIELDS SCENARIO

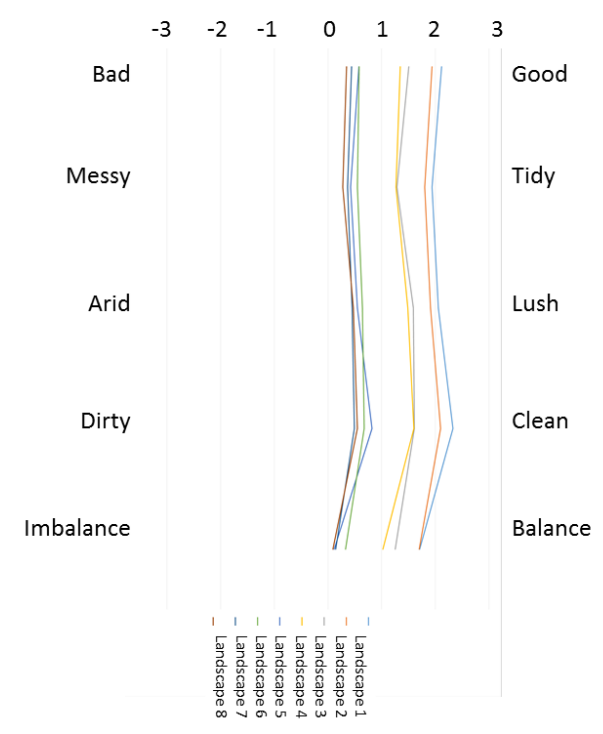

FIGURE 5. SD VALUE CHART OF CIBOER RICE FIELDS SCENARIO 


\section{Agro tourism Development Policy Recommendations}

Agro tourism activities will provide many benefits, both directly and indirectly, if managed properly. The development of agro tourism is one of several possible strategies to prevent the conversion of paddy fields, which is increasingly prevalent in Indonesia (Adimihardja, 2006; Franjaya, Syartinilia, \& Setiawan, 2018; Yanti et al., 2016). Agro tourism makes agricultural activities into a form of attraction so that sustainability is guaranteed. As stated by Aripin \& Yulianti (2018), agro tourism has a great opportunity to increase local revenue in Majalengka; Handayani, Jamhari, Waluyati, \& Mulyo (2019) and Sriyadi (2016) reported similar prospects from their research in Yogyakarta, as did Hwang \& Lee (2015) from research in Korea. More specifically, agro tourism activities can increase farmers' income in the Ciboer Rice Fields. Sugianto (2016) states that the development of a tourist village can increase the income of rural communities. Likewise, the report from Arifin, Wasman, \& Fitriyani (2017) states that tourism in Bantar Agung Village contributes to its economy.

For Bantar Agung Village, the benefits obtained from agro tourism activities occur not only from economic and ecological perspectives, but also from the local social and cultural standpoints, which have long been the culture of the local community. Palmer (2011) also states that agriculture and culture are two things that cannot be separated. Wardiningsih, Syahadat, Ramadan, Putri, \& Putra (2018) conducted a study of the importance of the agricultural landscape, which consists of historical, scientific, cultural, educational, and religious significance. Thus, it is possible that the agricultural landscapes of other regions in Indonesia are diverse and have different important values. This important value, if managed properly, will provide benefits to the community, both directly and indirectly.

As a feature of a tourism destination, natural beauty must be maintained for its sustainability. Changes in the behavior of tourists who like taking pictures to capture scenic images and take selfies are an indication of the importance of maintaining visual quality as an intangible resource. For this reason, it is necessary to draft clear regulations regarding tourism development, particularly to protect visual quality. The regulations that can be made in Bantar Agung Tourism Village are for the protection of visual resources because they are closely related to the development of village tourism, especially in the Ciboer Rice Fields area. For this regulation, legality and institutional clarity is very important because it can be used to prevent conflicts of interest. As stated, based on the results of the FGDs, the village was worried about the land ownership factor. If there is an increase in the demand for tourist facilities, individuals can easily add or subtract elements. In fact, from the results of the visual study, changes in elements have a significant effect on the visual quality of the landscape. Without beauty there will be no tourism activities and no economy (Ekayani et al., 2014; Vibriyanto et al., 2015). Furthermore, regulations regarding this protection must be introduced to the public to raise awareness about preserving natural beauty, which in turn will have a direct impact on economic improvement. Mak (2004) stated that unregulated tourism, starting from the very basics, can create environmental problems and ultimately endanger the environment itself. 


\section{CONCLUSIONS}

The visual quality of the Ciboer Rice Fields in Bantar Agung Village has a high value and is very sensitive to the addition of objects. Caution is needed in placing supporting facilities for agrotourism activities in the Ciboer Rice Fields area in ways that do not reduce visual quality, because the addition of objects to the broad middleground and foreground significantly reduces visual quality. The results of the visual quality evaluation research show that the addition of a massive object will reduce the visual quality and create a dirty and messy impression. For this reason, village regulations to protect the visuals of the Ciboer Rice Fields are absolutely necessary to protect the existing visual resources from being damaged.

\section{ACKNOWLEDGEMENTS}

Our thanks to (1) Bantar Agung Village, Majalengka Regency, West Java Province; (2) Agrotechnology Study Program, Gunung Jati Swadaya University; (3) Mathematics Tadris Study Program, Kendari State Islamic Institute; and (4) Landscape Architecture Study Program, National Institute of Science and Technology, who have facilitated valuable research.

\section{REFERENCES}

Adimihardja, S. (2006). Strategi Mempertahankan Multifungsi Pertanian di Indonesia. Jurnal Litbang Pertanian, 25(3), 99-105. http://203.190.37.42/publikasi/p3253064.pdf.

Adriani, H., Hadi, S., \& Nurisjah, S. (2016). Perencanaan Lanskap Kawasan Wisata Berkelanjutan di Kecamatan Cisarua, Kabupaten Bogor. Jurnal Lanskap Indonesia, 8(2), 53-69.

Anindisa, M., Basuni, S., \& Sunarminto, T. (2017). Stakeholder Pengelolaan Wisata Alam SPTN Wilayah II Majalengka Taman Nasional Gunung Ciremai (TNGC). Media Konservasi, 22(3), 230-241.

Arifin, D., Wasman, \& Fitriyani. (2017). Dampak Objek Wisata Curug Cipeuteuy terhadap Sosial Ekonomi dan Pendapatan Asli Daerah di Desa Bantaragung. Al-Mustashfa: Jurnal Penelitian Hukum Ekonomi Syariah, 2(2), 240-250. https://doi.org/10.24235/im.v2i2.2161

Arifin, N. H. S., \& Masuda, T. (1996). The Visual Impact of Building Development on Ritsurin Garden and Its Conservation. Journal of The Japanese Institute of Landscape Architecture, 60(4), 315-323. https://doi.org/10.5632/jila.60.315

Arifin, N. H. S., \& Masuda, T. (1997). Visitors' Judgements on the Scenery of Ritsurin Garden. Journal of the Japanese Institute of Landscape Architecture, 61(3), 259-262. https://doi.org/10.5632/jila.61.259 
Aripin, I., \& Yulianti, D. (2018). Potensi Keunggulan Lokal Kabupaten Majalengka dan Pemanfaatannya pada Pembelajaran Biologi. BIO EDUCATIO: The Journal of Science and Biology Education, 3(1), 43-52.

Budiyono, D. (2015). Evaluasi Estetika Lingkungan Berdasarkan Persepsi di Welcome Area Kampus Institut Pertanian Bogor. Buana Sains, 15(1), 19-28.

Budiyono, D., \& Soelistyari, H. T. (2016). Evaluasi Kualitas Visual Lanskap Wisata Pantai Balekambang di Desa Srigonco, Kabupaten Malang. Jurnal Lanskap Indonesia, 8(2), 8090.

Daniel, T. C., \& Boster, R. S. (1976). Measuring Landscape Aesthetic: The Scenic Beauty Estimation Method (Vol. 167). USDA.

Ekayani, M., Nuva, Yasmin, R., Sinaga, F., \& Maaruf, L. O. M. (2014). Wisata alam Taman Nasional Gunung Halimun Salak: Solusi Kepentingan Ekologi dan Ekonomi. Jurnal Ilmu Pertanian Indonesia (JIPI), 19(1), 29-37.

Franco, D., Franco, D., Mannino, I., \& Zanetto, G. (2003). The Impact of Agroforestry Networks on Scenic Beauty Estimation: The Role of A Landscape Ecological Network on A Socio-Cultural Process. Landscape and Urban Planning, 62(3), 119-138. https://doi.org/https://doi.org/10.1016/S0169-2046(02)00127-5

Franjaya, E. E., Syartinilia, \& Setiawan, Y. (2018). Modelling Landscape Change in Paddy Fields Using Logistic Regression and GIS. In IOP Conference Series: Earth and Environmental Science, The 4th International Symposium on LAPAN-IPB Satellite for Food Security and Environmental Monitoring (Vol. 149, p. 012002). IOP Publishing. https://doi.org/10.1088/1755-1315/149/1/012002

Hamdani, N. (2017). Evaluasi Estetika Air Pancuran pada Taman Suropati; Semantic Differential dan Scenic Beauty Estimation. Faktor Exacta, 10(4), 406-413.

Handayani, S. M., Jamhari, J., Waluyati, L. R., \& Mulyo, J. H. (2019). Kontribusi Pendapatan Agrowisata Padi Sawah Terhadap Pendapatan Rumah Tangga Pada Berbagai Kategori Desa Wisata. AGRARIS: Journal of Agribusiness and Rural Development Research, 5(1), $32-$ 42. https://doi.org/10.18196/agr.5173

Hwang, J., \& Lee, S. (2015). The Eeffect of The Rural Tourism Policy on Non-Farm Income in South Korea. Tourism Management, 46, 501-513. https://doi.org/10.1016/i.tourman.2014.07.018

Kumagai, Y., \& Yanase, T. (1985). Study on Evaluation System of Landscape Assessment. Journal of The Japanese Institute of Landscape Architecture, 48(5), 252-257. https://doi.org/10.5632/jila1934.48.5 252 
Mak, J. (2004). Tourism and the Economy: Understanding the Economics of Tourism. University of Hawai'i Press. Retrieved from http://www.jstor.org/stable/j.ctvvn7rt

Murna, S. A. P. G., Asmiwyati, I. G. A. A. R., \& Sukewijaya, I. M. (2020). Penilaian Kualitas Visual Beberapa Bentuk Tajuk Pohon di Median Jalan Prof. Dr. Ida Bagus Mantra Menggunakan Simulasi Komputer. Jurnal Arsitektur Lansekap, 6(1), 81-89. https://doi.org/10.24843/JAL.2020.v06.i01.p09

Muslih, I., Sunarminto, T., \& Avenzora, R. (2011). Evaluasi Ekoturisme di Taman Nasional Gunung Ciremai. Media Konservasi, 16(1), 7-17.

Palmer, B. (2011). Petani dan Pedagang: Perubahan Ekonomi dan Agama di Buton. Antropologi Indonesia, 32(1), 65-81. https://doi.org/10.7454/ai.v32i1.2113

Preeyanan, S., Pakkapong, P., \& Duanrung, B. (2015). Community Participation in Agrotourism Development at Klongplu,Khaokitchakood, Chanthaburi Province. Journal of Agricultural Technology, 11(8), 2071-2080.

Putra, R. T., Radnawati, D., Syahadat, R. M., Putra, P. T., \& Thoifur, D. M. (2018). Evaluasi Taman Jangkrik Sebagai RTRA Di Ciganjur, Jakarta Selatan. Prosiding Seminar Nasional Sains Dan Teknologi Fakultas Teknik Universitas Muhammadiyah Jakarta 2018, 1-6.

Putra, R. T., Ramadanti, P., Thoifur, D. M., Hestiningsih, H., Ramadhan, R. R., Syahadat, R. M., \& Putra, P. T. (2018). Ecomparism, sebuah Konsep Perencanaan Wisata Pantai Teloek Dalam - Bintan, Provinsi Kepulauan Riau. Jurnal Arsitektur Lansekap, 4(2), 233 242. https://doi.org/https://doi.org/10.24843/JAL.2018.v04.i02.p14

Rada, I. G. M., Utami, N. W. F., \& Astawa, I. N. G. (2019). Evaluasi Nilai Keindahan dan Indeks Kenyamanan Taman Kota Lumintan Denpasar. Jurnal Arsitektur Lansekap, 5(2), 150-159. https://doi.org/10.24843/JAL.2019.v05.i02.p02

Rejoni, R. (2017). Pemilihan Bentuk Tajuk Pohon dan Perdu yang Mendukung Tampilan Tampak Bangunan, Studi Kasus Bangunan Tanoto Forestry Information Center IPB, Bogor. Faktor Exacta, 10(4), 311-322.

Rohmadiani, L. D. (2011). Dampak Konversi Lahan Pertanian Terhadap Kondisi Sosial Ekonomi Petani (Studi Kasus: Jalur Pantura Kecamatan Pamanukan Kabupaten Subang). WAKTU: Jurnal Teknik UNIPA, 9(2), 71-81. https://doi.org/10.36456/waktu.v9i2.918

Saleh, I., Eviyati, R., Mardhatilla, F., \& Wahana, S. (2018). Penerapan Pertanian Sehat Desa Bantaragung Untuk Menjaga Kelestarian Ekosistem Kawasan Taman Nasional Gunung Ciremai (TNGC). JURNAL PRODIKMAS Hasil Pengabdian Kepada Masyarakat, 3(1), 1-7.

Saputra, Y. S., Susdiyanti, T., \& Supriono, B. (2012). Pengembangan Taman Wisata Curug Cipeuteuy Di Resort Bantaragung Seksi Pengelolaan Taman Nasional (SPTN) Wilayah II Majalengka Taman Nasional Gunung Ciremai. Jurnal Nusa Sylva, 12(2), 47-60. 
Satria, D. (2009). Strategi Pengembangan Ekowisata Berbasis Ekonomi Lokal Dalam Rangka Program Pengentasan Kemiskinan di Wilayah Kabupaten Malang. Journal of Indonesian Applied Economics, 3(1), 37-47. https://doi.org/10.21776/ub.jiae.2009.003.01.5

Sriyadi, S. (2016). Model Pengembangan Agrowisata Berbasis Kearifan Lokal (Studi Kasus di Desa Kebon Agung Kecamatan Imogiri Kabupaten Bantul DIY). AGRARIS: Journal of Agribusiness and Rural Development Research, 2(2), 152-160. https://doi.org/10.18196/agr.2236

Sugianto, A. (2016). Kajian Potensi Desa Wisata Sebagai Peningkatan Ekonomi Masyarakat Desa Karang Patihan Kecamatan Balong 1 Ponorogo. Ekuilibrium : Jurnal Ilmiah Bidang Ilmu Ekonomi, 11(1), 56-65. https://doi.org/10.24269/ekuilibrium.v11i1.113

Suliyanto. (2014). Statistika Non Parametrik: dalam Aplikasi Penelitian. Yogyakarta: CV. Andi Offset.

Syahadat, R. M., Putra, P. T., Patih, T., Thoifur, D. M., Nurhasanah, F., \& Saleh, I. (2019). Struktur Jalan Layang Provinsi DKI Jakarta: Sebuah Kajian Evaluasi Kualitas Visual. Jurnal Infrastruktur, 5(1), 45-50. https://doi.org/10.35814/infrastruktur.v5i1.617

Thoifur, D. M., Radnawati, D., Syahadat, R. M., Putra, P. T., Sagala, A. R., Pertiwi, S., \& Putra, R. T. (2018). Analisis Tapak Lanskap Wisata Curug Cipeuteuy Sebagai Zona Pemanfaatan Taman Nasional Gunung Ciremai. In Prosiding Seminar Nasional Sains dan Teknologi Fakultas Teknik Universitas Muhammadiyah Jakarta 2018 (pp. 1-10). Jakarta.

Utama, I. G. B. R. (2016). Keunikan Budaya dan Keindahan Alam sebagai Citra Destinasi Bali menurut Wisatawan Australia Lanjut Usia. Jurnal Kajian Bali, 6(1), 149-172.

Vibriyanto, N., Ismail, A., \& Ekayani, M. (2015). Manfaat Ekonomi dan Daya dukung Kawasan Pantai Lombang Kabupaten Sumenep Provinsi Jawa Timur. Risalah Kebijakan Pertanian Dan Lingkungan, 2(2), 152-159. https://doi.org/10.20957/jkebijakan.v2i2.10986

Wahana, S. (2018). Pertanian Organik dalam Persepsi Petani Desa Bantaragung sebagai Penjaga Kelestarian Kawasan Hutan TNGC. LOGIKA, 22(3), 51-57.

Wardiningsih, S., Syahadat, R. M., Putra, P. T., Purwati, R., \& Hasibuan, M. S. (2017). Konsep Perencanaan Tata Hijau Lanskap Sempadan Setu Mangga Bolong sebagai Area Konservasi Tumbuhan Bernilai Ekologis dan Budaya. NALARs Jurnal Arsitektur, 16(2), 135-144. https://doi.org/10.24853/nalars.16.2.135-144

Wardiningsih, S., Syahadat, R. M., Ramadan, B. C., Putri, A. E. T. D., \& Putra, P. T. (2018). Nilai Penting Lanskap Budaya Minapadi Desa Bunisari. IKRAITH-HUMANIORA, 2(2), 95-100. 
Yanti, N. K. D., Lila, K. A., \& Yusiana, L. S. (2016). Studi Potensi Subak Tanah Yeng sebagai Kawasan Agrowisata di Desa Sedang, Kecamatan Abiansemal, Kabupaten Badung. Jurnal Arsitektur Lansekap, 2, 155-164. https://doi.org/10.24843/JAL.2016.v02.i02.p06

Yuniarsih, A., Marsono, D., Pudyatmoko, S., \& Sadono, R. (2014). Zonasi Taman Nasional Gunung Ciremai Berdasarkan Sensitivitas Kawasan dan Aktivitas Masyarakat. Jurnal Penelitian Hutan Dan Konservasi Alam, 11(3), 239-259. https://doi.org/10.20886/iphka.2014.11.3.239-259

Yuningsih, Y., \& Herdiansyah, H. (2019). The Role of Management Institution of the Ciremai Mountain National Park in Encouraging Public Participation. SOSHUM: Jurnal Sosial Dan Humaniora, 9(1), 26-38. 